\title{
Efforts Towards the Development of New Antitubercular Agents: Potential for Thiolactomycin Based Compounds
}

\author{
Ahmed Kamal, * Shaik Azeeza, M. Shaheer Malik, Ahmad Ali Shaik and Maddamsetty V. Rao \\ Chemical Biology Laboratory, Division of Organic Chemistry, Indian Institute of Chemical Technology, Hyderabad, India.
}

Received April 28, 2008; Revised August 27, 2008; Accepted September 3, 2008; Published September 5, 2008.

\begin{abstract}
Development of new chemotherapeutic drugs is the need of the hour to improve tuberculosis control, particularly in the developing world. In the last fourty years no new compound has been brought to the market for the treatment of tuberculosis. However, in recent years there is an enhanced activity in the research and development of new drugs for TB. Some compounds are presently in clinical development, while others are being investigated pre-clinically in an attempt to explore new molecules for the target based treatment of TB. Simultaneously some new targets are being identified and validated for their practical usefulness. Structures based on thiolactomycin could have considerable potential in the development of target based anti-TB agents. The present review provides an overview of the drugs that are being clinically used and the compounds that are in advanced stages of clinical as well as preclinical studies. We have also attempted to highlight the efforts that are being made in the development of new molecules based on thiolactomycin as lead compound, including studies from this laboratory.
\end{abstract}

\section{INTRODUCTION: TUBERCULOSIS AN OVERVIEW}

\section{Background}

Mycobacterium tuberculosis, which causes tuberculosis (TB), is a slow growing bacterium and was evolved more than ten thousand years ago from a soil bacterium (1). Tuberculosis is a respiratory transmitted disease affecting nearly $32 \%$ of the world's population, more than any other infectious disease. Among the infected individuals, approximately eight million develop active TB and almost two million of these die from this disease per year. Of new TB cases, 95\% occur in developing countries every year and approximately one million young women per year are victimized with this disease in the developing world (2-6). The occurrence of this disease is linked to dense population, poor nutrition, and poor sanitation (7). Tuberculosis, an airborne communicable disease caused by transmission of aerosolized droplets of Mycobacterium tuberculosis (8). The primary source of infection is viable tubercular bacilli, expelled in the environment by a patient with active TB.

Mycobacterium is a genus of bacteria, which grows slowly under aerobic conditions and is distinguished by acid-fast staining. They are Grampositive, non-motile, rod-shaped, obligate aerobic bacteria that belong to the order actinomycetales, family Mycobacteriaceae (9). Several species, including Mycobacterium tuberculosis, M. bovis, M. africanum, M. microti, M. avium, and M. leprae, are intracellular pathogens of higher vertebrates (10). The cell wall of Mycobacterium species in its full structural and functional integrity is essential for its growth and survival in the infected host. $M$. tuberculosis possesses a cell wall dominated by covalently linked mycolic acids, arabinogalactan and peptidoglycan (AGP), the mycolic acids of which are complimented by glycolipids such as $\alpha, \alpha-$ trehalose monomycolate (TMM) (11). This mycolic acid based permeability barrier shields the organism from environmental stress and contributes to disease persistence and the refractoriness of $M$. tuberculosis to many antibiotics (12).

One of the most prominent macromolecular entities of mycobacterial cell wall is arabinan, a common constituent of both arabinogalactan (AG) and lipoarabinomannan (LAM) (13).

\footnotetext{
Corresponding Author. Ahmed Kamal; Chemical Biology Laboratory, Division of Organic Chemistry, Indian Institute of Chemical Technology, Hyderabad, 500007 A.P. India. E-mail: ahmedkamal@,iict.res.in
} 
In the chemical setting of mycolylarabinogalactanpeptidoglycan complex, AG forms an integral part of the cell wall proper, whereas LAM, based on a phosphatidylinositol anchor, apparently exists in a state of flux. LAM is an essential part of the cell wall core, anchored in the cell membrane and transversing the cell wall as well as appearing as an excretory product. LAM has been implicated as a key surface molecule in host-pathogen interactions. The biosynthetic pathways leading to the formation of the key mycobacterial cell wall components AG and mycolic acids are the target for the rational design of new antitubercular agents. The complete genome sequence of the best-characterized strain of M. tuberculosis H37Rv has been determined (14). Moreover, the TB-structural genomics consortium has undertaken an extensive study to determine and analyze the structures of over 400 proteins from $M$. tuberculosis including 40 novel folds and 200 new families of protein structures. The database of linked structural and functional information generated will have lasting impact in understanding the $M$. tuberculosis pathogenesis and for structure based drug design (15). Further, recent strategies that target various pathways related virulence, including inhibition toxin function, toxin delivery, regulation of virulence expression and bacterial adhesion could provide a number of new targets for novel antitubercular drugs (16).

\section{Tuberculosis-HIV Combination}

The current estimations reveal that one-third of the 42 million people living with HIV/AIDS worldwide are co-infected with TB (17). As per WHO reports, approximately $90 \%$ of the patients having both TB and HIV died within a few months after clinical symptoms. Therefore, WHO warned the world for "even greater TB-HIV crisis" and called for wide availability of free anti-TB drugs to those living with HIV. As per WHO, HIV is spreading rapidly in India with the largest number of TB cases in the world (18-21).

\section{Drug-resistant tuberculosis (MDR-TB and XDR- TB)}

Drug resistance displayed by $M$. tuberculosis is an important obstacle for the treatment and control of TB. This resistance has traditionally been attributed to the unusual multi-layer cell envelope and active multidrug efflux pumps. Recent insights into mechanisms that neutralize the toxicity of antibiotics in the cytoplasm have revealed other systems that function in synergy with the permeability barrier and efflux systems to provide natural resistance. Drugs inhibiting these intrinsic systems would enable many antibiotics, which are already available but have not been used for $\mathrm{TB}$, to gain new activities against $M$. tuberculosis.

The term multidrug-resistance tuberculosis (MDRTB) refers to simultaneous resistance to at least two or more of the five first-line anti-TB drugs (isoniazid, rifampicin, pyrazinamide, ethambutol, and streptomycin) (22-24). Multi-drug-resistance arises from sharing of genes between different species or genera, generally mediated by small pieces of extra-chromosomal DNA known as transposons or plasmids (25). Treatment for multidrug-resistant tuberculosis is long lasting, less effective, costly, and poorly tolerated. The most recent estimates suggest that, globally there were about 4.89 lakhs cases of MDR-TB in 2006. These cases were very unevenly spread with $86 \%$ of the cases are reported from 27 countries, of which 15 are in Eastern Europe (26).

Extensively drug resistant (XDR) tuberculosis by definition is resistance to at least isoniazid and rifampicin in addition to any quinolone and at least one injectable second-line agent (capreomycin, amikacin, kanamycin). The principles of treatment for MDR-TB and XDR-TB are the same. The main difference is that XDR-TB is associated with a much higher mortality rate than MDR-TB, because of reduced number of effective treatment options. Hence there is an urgent need for novel drugs that are active against $M$. tuberculosis in order to shorten the duration of tuberculosis therapy.

\section{FIRST LINE ANTI-TUBERCULAR AGENTS}

Chemotherapy of TB has started in the 1940's with anti-TB research resulting in the discovery of active anti-TB agents, and newer strategies have been devised in recent years to treat TB (27-30). The important first-line antitubercular drugs, which include streptomycin (SM), isoniazid (INH), rifampicin (RMP), ethambutol (EMB) and pyrazinamide (PZA) and their mechanism of action is discussed below. 


\section{Streptomycin}

Streptomycin (SM) $\mathbf{1}$ is an aminoglycoside antibiotic isolated from Streptomyces griseus and consists of three structural components, streptidine, streptose and $N$-methyl-L-glucosamine. Because of its poor absorbance in the gastrointestinal tract, it is administered intramuscularly and only very occasionally by intrathecal route. Streptomycin was the first really effective drug against $T B$, and derivatives of dihydrostreptomycin 2 also have antiTB activities (Figure 1). Mutations in the rpsL gene of ribosomal S12 protein of mycobacteria or base substitutions in the $16 \mathrm{~S}$ rRNA region confer resistance to streptomycin 1 (31).

Due to many toxic manifestations in the peripheral and central nervous system at higher doses and hypersensitivity reactions, it is not a drug of popular choice. Although dihydrostreptomycin 2 once was thought to be less toxic, it in fact causes severe damage to the eighth cranial nerve, inducing irreversible impairment of auditory function.

\section{Isoniazid}

Isoniazid (INH) 3 is a synthetic derivative from 4pyridine carboxylic acid. The $M$. tuberculosis kat $\mathrm{G}$ gene encodes a dual function enzyme called catalase peroxidase, which confers sensitivity in $M$. tuberculosis to isoniazid. It is a prodrug that requires activation by the mycobacterial catalase peroxidase enzyme (kat G) into an active form, which then exerts a lethal effect on intracellular targets. INH is orally active and exhibits bacteriostatic action on resting bacilli and is highly active against the $M$. tuberculosis complex ( $M$. tuberculosis, M. bovis, M. africanum and $M$. microti). It has very low MICs $(0.02-0.06 \mu \mathrm{g} / \mathrm{mL})$ against these pathogens (32). It enters the organism by diffusion and oxygen-dependent active transport, and it has been reported to have an effect on almost every aspect of mycobacterial metabolism (33). INH inhibits the mycolic acid biosynthesis in $M$. tuberculosis by affecting the enzyme mycolate synthetase, unique for Mycobacteria (34, 35). A mutation within the mycobacterial inhA gene has shown to confer resistance to INH in $M$. smegamatis and in M. bovis, suggesting that inhA is the likely target of this drug.

\section{Rifamycins}

Rifamycins RIF (rifampicin 4, rifabutin 5, rifapentine 6) belong to the family of ansamycin antibiotics, so named because of their basket-like molecular architecture comprising an aromatic moiety bridged at non adjacent positions by an aliphatic chain (Latin: ansa= handle) (36-39). Rifamycins are a group of semisynthetic antibiotics of rifamycin B, isolated from Streptomyces mediterrani with a characteristic structure in which the chromophoric naphthaquinone group is spanned by a long aliphatic bridge which itself has very poor antimicrobial activity (40). They inhibit prokaryotic DNA-dependent RNA polymerase, an enzyme necessary for RNA synthesis (41) and acts on $\beta$ subunit of this enzyme resulting in the formation of a stable complex. However, a combination of isoniazid and rifampicin may increase a risk of hepatotoxicity. It is effective against $M$. tuberculosis with MIC ranging from 0.1 to 0.2 $\mu \mathrm{g} / \mathrm{mL}$.

\section{Ethambutol}

Ethambutol (EMB) is a synthetic aminoalcohol 7 (ethylene diamino-di-l-butanol), an orally effective bacteriostatic agent that is active against most strains of Mycobacterium (42-44). The proposed site of action of this first-line drug ranges from trehalose dimycolate, mycolate and glucose metabolism to spermidine biosynthesis. However, recent studies provided evidence that the primary site of action is arabinan biosynthesis both in arabinogalactan and LAM. Activity of EMB is stereospecific and the dextro isomer exhibited maximum anti-tubercular activity $(S, S$ form is 600 times more active than $R, R)(45)$.

\section{Pyrazinamide}

Pyrazinamide (PZA) 8, a structural analogue of nicotinamide, is another first-line drug for short course TB therapy. It is also active against semidormant bacilli not affected by any other drug, has strong synergy with INH and RMP, and shortens the therapy period to six months (46-47). The drug has no significant bactericidal effect and is thought to act via a sterilizing effect. The activity of PZA depends on the presence of bacterial amidase, which converts PZA to pyrazinoic acid, 
the active anti-TB molecule. Mutation in the pncA gene responsible for the production of pyrazinamidase has been shown to be the reason for resistance against this drug (48-49).

\section{SECOND LINE ANTI-TB DRUGS}

According to WHO there are six classes of secondline drugs that are used in the treatment of tuberculosis (50). A drug may be classified as a second-line because of one of two possible reasons: 1) it may be less effective than the first-line drugs or it may have toxic side-effects or 2) it may be unavailable in many developing countries. These comprise of different classes namely, aminoglycosides: (amikacin, kanamycin), polypeptides: (capreomycin, viomycin), fluoroquinolones: (ciprofloxacin, moxifloxacin), thioamides: (ethionamides, prothioamide), cycloserine and $p$-aminosalicylic acid

\section{Amikacin and kanamycin}

Amikacin 9 is a aminoglycoside antibiotic used for the treatment of different types of bacterial infections including $M$. tuberculosis (51). It acts by binding to the bacterial $30 \mathrm{~S}$ ribosomal subunit, causing misreading of mRNA and thus leaving the bacterium unable to synthesize proteins vital to its growth (52). It is most often used for treating severe, infections with multidrug resistant bacteria. However, amikacin causes kidney damage as well as hearing loss. Kanamycin $\mathbf{1 0}$ also belongs this class and has similar properties (Figure 2) (53).

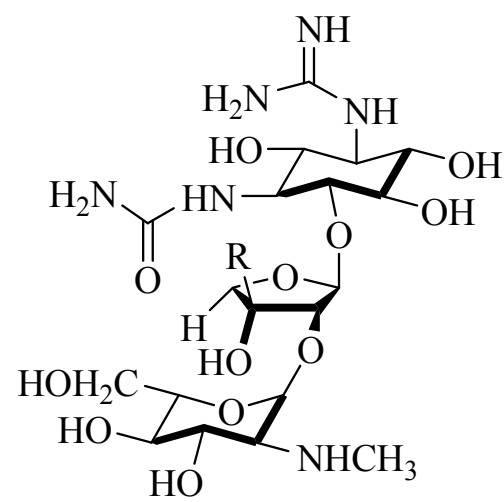

$\mathrm{R}=\mathrm{CHO} \quad$ Streptomycin $\mathbf{1}$

$\mathrm{R}=\mathrm{CH}_{2} \mathrm{OH}$ dihydrostreptomycin 2

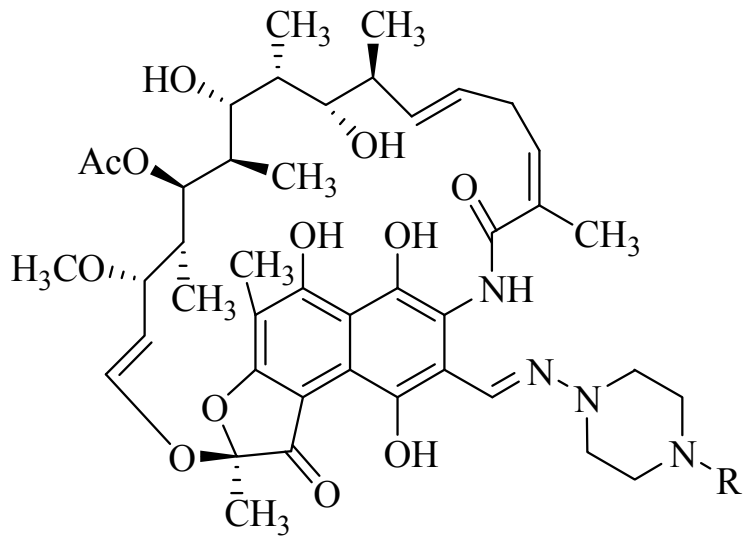

$\mathrm{R}=\mathrm{CH}_{3}$ Rifampicin 4

$\mathrm{R}=\mathrm{CH}_{2} \mathrm{CH}\left(\mathrm{CH}_{3}\right)_{2}$ Rifabutin 5

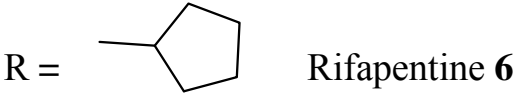<smiles>NNC(=O)c1ccncc1</smiles>

Isoniazid 3<smiles>CC[C@H](CO)NCCN[C@H](CC)CO</smiles>

Ethambutol 7<smiles>NC(=O)c1cnccn1</smiles>

Pyrazinamide 8

Figure 1. 
<smiles>NCC[C@H](O)C(=O)NC1C[C@H](N)[C@H](O[C@@H]2O[C@H](CN)[C@@H](O)C(O)[C@H]2O)[C@H](O)[C@H]1O[C@H]1O[C@H](CO)[C@@H](O)[C@H](N)[C@H]1O</smiles>

Amikacin 9

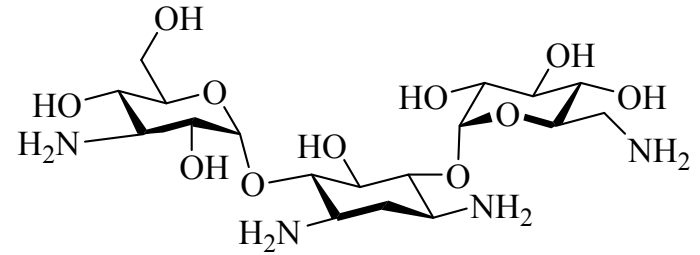

Kanamycin $\mathbf{1 0}$

Figure 2.

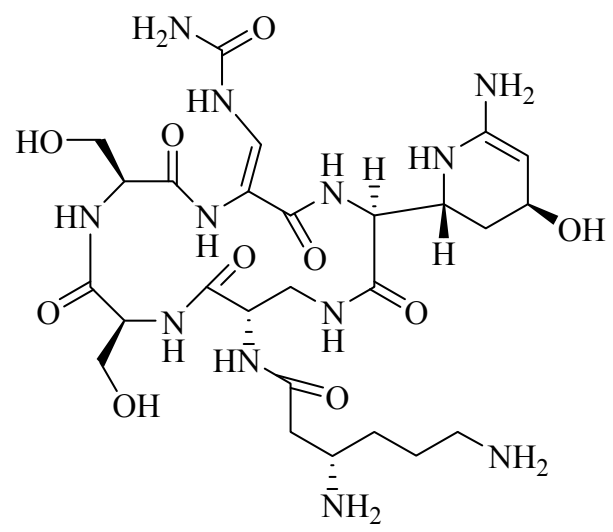

Viomycin 11<smiles></smiles>

Capreomycin 12

Figure 3.

\section{Viomycin and capreomycin}

Viomycin $\mathbf{1 1}$ is an polypeptide antibiotic used for the treatment of tuberculosis. It is produced by the actinomycete Streptomycespuniceus that binds to RNA and inhibits prokaryotic protein synthesis and certain forms of RNA splicing (54). Capreomycin 12 also belongs to this class of antibiotic, which is given in combination with other antibiotics for treating tuberculosis (Figure 3). Unfortunately, it exhibits adverse effects including nephrotoxicity and eighth cranial nerve toxicity (55).

\section{Fluoroquinolones}

Fluoroquinolones (7-fluoro-4-oxo-1,4-dihydroquinoline-3-carboxylic acid) are an important class of fluorine containing compounds (Figure 4). This class possesses potent antibacterial activity with a broad spectrum of activities against gram-positive, gram-negative and mycobacterial organisms as well as anaerobes with great therapeutic potential, particularly those resistant to other classes of antibacterial drugs (56). A large number of fluoroquinolones have been synthesized with further improvement, such as the solubility, 
antimicrobial activity, prolonged serum half-life, lesser adverse side-effects and both oral and parenteral routes of administration. Some notable examples of this class are ciprofloxacin 13, moxifloxacin 14, ofloxacin 15 (levofloxacin 15a, the chiral form of ofloxacin is more effective), gatifloxacin 16 ( $S$-form is more effective), trovafloxacin 17, enofloxacin 18 and sparfloxacin 19 etc. $(56,57)$.

Ciprofloxacin 13 and moxifloxacin 14 are broad spectrum antibiotics, active against Grampositive and Gram-negative bacteria. They function by inhibiting DNA gyrase, a type II topoisomerase, which is an enzyme necessary to separate replicated DNA, thereby inhibiting cell division (58). Fluoroquinolones are increasingly contraindicated for patients due to growing prevalence of antibiotic resistance.

\section{Thioamides}

The two main drugs from the thioamide (or thionamide) family that can be used for treatment of TB are ethionamide and prothionamide are structural analogues of isoniazid (Figure 5). Ethionamide (ETA: 2-ethyl thioisonicotinamide) 19 and prothionamide (PTA: 2-propyl thioisonicotinamide) 20, are important drugs of second-line therapy for MDR-TB (59). ETA and PTA have almost identical inhibitory effects on mycolic acid biosynthesis as INH.<smiles>O=C(O)c1cn(C2CC2)c2cc(N3CCNCC3)c(F)cc2c1=O</smiles>

Ciprofloxacin 13<smiles>COc1c(N2CC3CCCNC3C2)c(F)cc2c(=O)c(C(=O)O)cn(C3CC3)c12</smiles>

Moxifloxacin 14

$R / S:$ Ofloxacin 15

$S$ : Levofloxacin 15a<smiles>NC1[C@H]2CN(c3cc4c(cc3F)c(=O)c(C(=O)O)cn4-c3ccc(F)cc3F)C[C@H]12</smiles>

Trovafloxacin $\mathbf{1 7}$<smiles>CCn1cc(C(=O)O)c(=O)c2cc(F)c(N3CCNCC3)nc21</smiles>

Enofloxacin 18<smiles>C[C@H]1CN(c2c(F)c(N)c3c(=O)c(C(=O)O)cn(C4CC4)c3c2F)C[C@@H](C)N1</smiles>

Sparfloxacin 19

Figure 4. 
ETH is active against $M$. tuberculosis, M. leprae, $M$. kansasii, and some strains of the M. avium complex (60). Adverse effects associated with ETH and PTA are gastrointestinal disorders (such as anorexia, salivation, nausea, abdominal pain, and diarrhea), diverse mental disturbances (such as depression, anxiety psychosis, dizziness, drowsiness, and headache) and hypersensitivity skin reactions, side effects which restrict their common usage (61).

\section{Cycloserine}

D-Cycloserine (Cs) 21 a structural analogue of the amino acid D-alanine, possess an oral broad spectrum antibiotic effective against $M$. tuberculosis, by inhibition of cell wall synthesis at an early stage of peptidoglycan synthesis (61). The side effects of this drug are mainly CNS manifestations such as headache, irritability, depression, convulsions (62).

\section{p-Aminosalicylic acid}

p-Aminosalicylic acid (PAS) 22 is an antimycobacterial agent and is used in combination with isoniazid and streptomycin (63). PAS exerts a bacteriostatic effect on $M$. tuberculosis by competitively blocking the conversion of $p$ aminobenzoic acid into folic acid but is less effective.<smiles>CCc1cc(C(N)=S)ccn1</smiles>

Ethionamide 19<smiles>CCCc1cc(C(N)=S)ccn1</smiles>

Prothionamide 20<smiles>N[C@@H]1CONC1=O</smiles>

Cylcoserine $\mathbf{2 1}$<smiles>Nc1ccc(C(=O)O)c(O)c1</smiles>

p-Aminosalicylic acid 22

Figure 5.

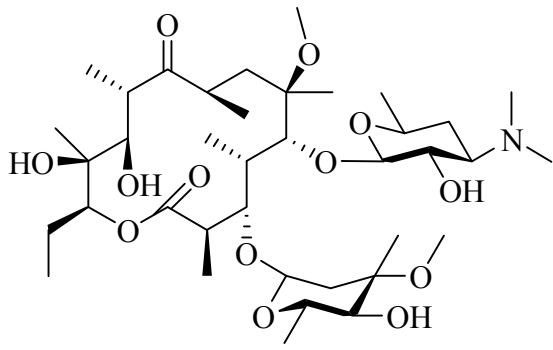

Clarithromycin 23<smiles>CC(=O)Nc1ccc(/C=N/NC(N)=S)cc1</smiles>

Thioacetazone 24<smiles>CSC1=CC2C(C=C1)Sc1ccccc1N2CC[C@@H]1CCCCN1C</smiles>

Thioridazine 25

Figure 6. 
Now, the situation is further complicated by the emergence of multidrug-resistant $\mathrm{TB}$ and by infections with lethal synergy with HIV/AIDS. Patients with MDR-TB are being treated with a combination containing second line drugs that are less effective, more expensive and higher toxicity. TB's lethal synergy with HIV/AIDS puts HIVpositive individuals with latent tubercle bacilli infection (LTBI) at a greater risk of developing active $\mathrm{TB}$, making $\mathrm{TB}$ as the number one killer among patients with AIDS.

The pharmaceutical industry however, has generally shown little interest in developing new, more effective drugs to address these needs, and as a result, no new anti-TB agent with a novel mechanism of action has been launched since the introduction of RFP in 1966. Consequently, global health and philanthropic organizations are now pleading for new chemotherapy interventions that can shorten the total duration of therapy, provide improved efficacy against MDR-TB, safely treat patients co-infected with HIV/AIDS, and target LTBI.

\section{RECENTLY DISCOVERED TUBERCULAR AGENTS}

ANTI-

The recommended five first-line drugs for standard treatment regimen are highly effective and the rate of severe adverse reactions is low. However, unpleasant side effects and a relatively long duration of treatment are drawbacks, which also increase the rate of non-compliance to treatment regimen. Such non-adherence with the course of treatment leads to treatment failure and the development of drug resistance. The second line drugs used for MDRTB are more expensive, less effective and more toxic than the five drug standard regimen.

The goal now is to develop bactericidal drugs in a cost-effective manner, which efficaciously treats infectious MDR strains of $M$. tuberculosis and latent infections with shortened treatment periods as well as reduced frequency of dosage. Some of recently discovered anti-Tb agents are discussed below.

\section{Tryptanthrin}

Tryptanthrin $\mathbf{2 6}$ is a potent structurally novel indoloquinazolinone alkaloid, active against MDR strains of $M$. tuberculosis and the MIC value of it is $0.5-1.0 \mu \mathrm{g} / \mathrm{mL}$. After the determination of the toxicity data, this structural prototype can possibly be utilized in MDR TB therapy (68).

\section{Nitroimidazopyrans and nitroimidaoxazoles}

A series of bicyclic nitroimidazopyrans (NAP) have recently been reported to possess anti-tubercular activity (Figure 7). One of the compounds, PA-824 (27) has emerged as a lead molecule as it is effective against both replicating and latent $M$. tuberculosis cells with a MIC ranging from 0.015 to $0.25 \mu \mathrm{g} / \mathrm{mL}$. Poly and multi-drug resistant strains are susceptible to PA-824, indicating that there is no cross-resistance with current drugs (69). The mode of action of this class of compound is by a mechanism dependent on $M$. tuberculosis F420 cofactor, inhibition of protein biosynthesis and cell wall lipids (69). Another orally active analog PA 1343 (28) has been developed and is in preclinical studies with MIC of $0.015 \mu \mathrm{g} / \mathrm{mL}$ (70). The compound OPC-67683 (29), a nitro-dihydroimidazooxazole derivative is found to possess higly potent activity against TB, including MDR-TB at a concentration (MIC) range of 0.006-0.024 $\mu \mathrm{g} / \mathrm{mL}$.

\section{Oxazolidinones}

Oxazolidinones are totally synthetic, orally active anti-bacterial agents developed by DuPont $(71,72)$. They are bacterial protein synthesis inhibitors, with inhibition uniquely in the initiation phase of protein synthesis. Some of the morpholine and thiomorpholine analogues of oxazolidinones like linezolid 30 and U-100480 (31) have shown potent in vitro activity against $M$. tuberculosis whereas the other oxazolidinone derivatives $(32,33)$ displays lethal toxicity in the rat models (73) as shown in Figure 8 .

\section{Clofazimine Analogues}

The tetramethyl piperidine substituted phenazines B4169 (34) and B4128 (35) (TMP phenazines) have been found to possess significantly more activity against $M$. tuberculosis, including MDR clinical strains than clofazimines 36 (74). 
<smiles>O=C1c2ccccc2N2C(=O)c3ccccc3NC12</smiles>

Triptanthrin 26<smiles>O=[N+](O)c1cn2c(n1)OC[C@@H](OCc1ccc(OC(F)(F)F)cc1)C2</smiles>

PA-824 (27)<smiles>C[C@]1(COc2ccc(N3CCC(Oc4ccc(OC(F)(F)F)cc4)CC3)cc2)Cn2cc(N(O)O)nc2O1</smiles>

OPC-67683 (29)<smiles>O=C(N[C@H]1COc2nc([N+](=O)[O-])cn2C1)c1ccc(OC(F)(F)F)cc1</smiles>

PA-1343 (28)

Figure 7.

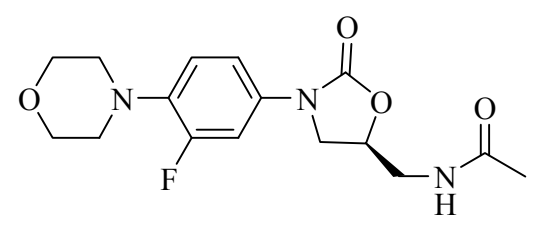

Linezolid (30)

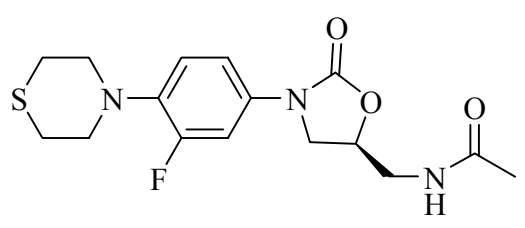

U-100480 (31)

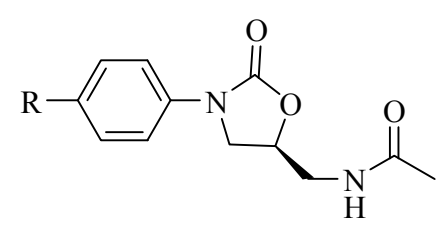

DuP $721 \mathrm{R}=\mathrm{MeCO}$ (32)

DuP $105 \mathrm{R}=\mathrm{MeSO}$ (33)

Figure 8.

The most important virtues of tetramethyl phenazines are intracellular accumulation in mononuclear phagocytic cells, anti-inflammatory activity, a low incidence of drug resistance and slow metabolic elimination rate, which make them attractive candidates for the treatment of mycobacterial infections (Figure 9).

Recently, in this laboratory new conjugates of phenazine with phthalimido and naphthalimido moieties $\mathbf{3 7}$ have been designed and synthesized as antitubercular compounds (75). Some of the compounds in this new class of phenazine hybrids have shown promising results in the inhibition of M. tuberculosis ATCC 27294 as well as their clinical isolates (sensitive and resistant). This study revealed that there is a potential to design such type of phenazine hybrids for the development of new antitubercular agents.

\section{Nitrofuranyl amides}

Lee and co-workers (76) have prepared a series of nitrofuran derivatives which were tested for MIC activity against $M$. tuberculosis H37Rv. One of the compound $\mathbf{3 8}$ in this series has shown excellent $\mathrm{MIC}_{90}$ value $0.025 \mu \mathrm{g} / \mathrm{mL}$, which is comparable to that of the frontline anti-tubercular agents like isoniazid and ethambutol. Structure-activity relationship studies have shown that the nitro group is necessary for biological activity.

\section{Purines}

9-Benzylpurines, with a variety of substituents on 2 , 6 and/or 8 position, have been shown to possess high inhibitory activities against $M$. tuberculosis (Figure 10). 
<smiles>CC1(C)CC(N=c2cc3n(-c4cc(Cl)c(Cl)c(Cl)c4)c4ccccc4nc-3cc2Nc2cc(Cl)c(Cl)c(Cl)c2)CC(C)(C)N1</smiles>

34<smiles>CC1(C)CC(/N=c2/cc3n(-c4ccc(Cl)c(Cl)c4)c4ccccc4nc-3cc2Nc2ccc(Cl)c(Cl)c2)CC(C)(C)N1</smiles>

35<smiles>CC(C)N=c1cc2n(-c3ccc(Cl)cc3)c3ccccc3nc-2cc1Nc1ccc(Cl)cc1</smiles>

36<smiles>[R]C[R]CCCN1CCN([Y10]N=c2cc3n(-c4ccc(Cl)cc4)c4ccccc4nc-3cc2Nc2ccc(Cl)cc2)CC1</smiles>

37 $\mathrm{n}=0,1,2,3$

Figure 9.<smiles>O=C(NCc1ccc(N2CCN(Cc3ccccc3)CC2)c(F)c1)c1ccc([N+](=O)[O-])o1</smiles>

38

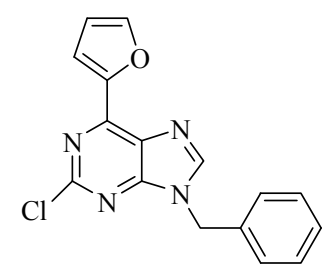

2-Chloro-4-(2-furanyl)-9-benzopurine 39

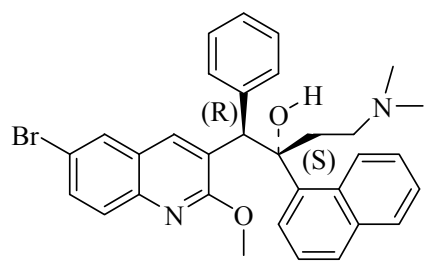

R207910 40

Figure 10.

One of the compounds, $\mathbf{3 9}$ belonging to the above class carrying trans-styryl or aryl substituents at 6 position and generally chlorine in 2 position tends to increase the activity and has MIC of $0.78 \mathrm{mg} / \mathrm{mL}$ in vitro (77). Antimycobacterial activity of 6arylpurines (78) and 9-sulphonylated or sulphenylated-6-mercaptopurines are also known in the literature (79).

\section{Diarylquinolines}

Diarylquinolines (DARQs) are structurally different from both fluoroquinolones and other quinoline classes. The DARQ R207910 (40) is a member of a new chemical class of antimycobacterial agents and has a MIC value equal to or lower than reference compounds. It has a unique specificity towards mycobacteria including atypical species important in humans such as MAC, M. kansai, and the fast growers $M$. fortium and $M$. abscessus (80). This antimycobacterial specific spectrum differs from that of isoniazid, which has very poor activity against MAC. The clinical use of this will be highly targeted to the treatment of the mycobacterial infections, particularly targeting the proton pump of adenosine triphosphate (ATP) synthase (81). 


\section{1,2,4-Benzothiadiazines}

Sulfonamides are well known for their antibacterial property and a large number of such compounds have been developed as antimicrobial agents (8284). 1, 2, 4-benzothiadiazine dioxides have a close relation to sulfonamide and could be considered as cyclic sulfonamide class of molecules. These compounds are well known for a variety of biological properties, including antimicrobial activity $(85,86)$. Based on this finding and within a research program in this laboratory to develop new antitubercular agents - the 1,2, 4-benzothiadiazine system was explored by incorporating other heterocyclic rings like pyridine and pyrazine moieties 41, 42 (Figure 11). Studies in this direction have afforded some molecules based on 1, 2, 4benzothiadiazine system that exhibited interesting antitubercular activity $(87,88)$. Studies in this direction have afforded some molecules based on 1 , 2, 4-benzothiadiazine system that exhibited interesting antitubercular activity.

Several other molecules like pyrroles 43 , (89) quinoxaline-1,4-dioxides 44 (90) and alkylsulfinyl amides 45, (91) etc. have also been prepared and tested for their antimycobacterial activity. Recently some new targets such as signaling kinase inhibitors have been investigated. The survival of $M$. tuberculosis against the macrophage phagocytosis relies not only on a thick cell wall but also on many mycobacterial kinases and phosphatases which disrupt the host-cell defence mechanism against parasitism (92-94). Histidine kinase is the focus for the specific inhibition of two component signal transduction system in mycobacteria (95-98). Based on this signal transduction system, a series of antimycobacterial salicylanilides and related compounds have been reported (99-102). Inhibition of this type of regulation has been involved in the virulence of $M$. tuberculosis in mice (103). Eleven putative eukaryotic-like protein serine-threonine kinases (Pkn A to L) involved in signal transduction have been identified in $M$. tuberculosis H37Rv genome $(11,104-106)$. Based on this kinase inhibition benzothiophenes (specifically inhibits Pkn G) $(107,108)$ and benzoquinoxalines (inhibitors of Pkn B, Pkn G, and Pkn H) (109-112) have been reported. Hence this intensive research on signaling kinase inhibitors could also provide target oriented lead molecules for the control of tuberculosis.

In view of the persistent drug-resistant $\mathrm{TB}$ problem, it is important that new drugs should address different targets, as those of currently used drugs including the shortening of TB therapy. The unique structure of the mycobacterial cell wall makes it a useful target for drug development and studies can be directed to specific sites like cell wall biosynthetic pathways (113). Thiolactomycin inhibits mycobacterial fatty acid synthase and the elongation steps of mycolic acid biosynthesis (114), with negligible toxicity and thus structures based on this lead could provide a new class of antibiotics against tuberculosis.

\section{THIOLACTOMYCIN}

Naturally occurring (5R)-thiolactomycin (TLM, 46) exhibits potent in vivo activity against many pathogenic bacteria, including Gram-negative and Gram-positive bacteria and M. tuberculosis (114116). TLM inhibits bacterial and plant type II fatty acid synthases (FAS-II) but not mammalian or yeast type I fatty acid synthases (FAS-I) (117). In Escherichia coli, it inhibits both $\beta$-ketoacyl-ACP synthase I to III and acetyl coenzyme A (CoA): ACP transacylase activities in in vivo and in vitro conditions $(118,119)$ (Figure 12).

\section{Introduction}

Thiolactomycin (TLM, 46) is a thiolactone antibiotic isolated from a soil sample collected in Sayama city, Saitama prefecture, Japan. It is obtained from fermentation broth of Nocardia species, a strain of actinomycetes and has a unique chemical structure with no chemical relation to any group of known antibiotics $(120,121)$. This antibiotic has been detected in the fermentation broth by the use of the $\beta$-lactam antibiotic-sensitive mutant of Pseudomonas aeruginosa M-57740. The structure and antibiotic properties of TLM have been first reported by Oishi and coworkers in 1982 and it is the first naturally occurring thiolactone to exhibit antibiotic activity (120). 
<smiles>[Y][Z]1[Z]=CC(C(=O)NNC2=NS(=O)(=O)c3cc([R])ccc3N2[R])=[Y]C1</smiles>

41<smiles>[Y][X]c1c[Y]c(C(=O)NC2=NS(=O)(=O)c3cc([R])ccc3N2[R])c1</smiles>

42

$\mathrm{R}^{1}=\mathrm{H}, \mathrm{Cl}$

$\mathrm{R}^{1}=\mathrm{H}, \mathrm{Cl}$,

$\mathrm{X}=\mathrm{CH}, \mathrm{N}$

$\mathrm{Y}=\mathrm{CH}, \mathrm{N}$

$\mathrm{Z}=\mathrm{CH}, \mathrm{N}, \mathrm{CCl}$<smiles>Cc1c(CN2CCN(C)CC2)cc(-c2ccc(Cl)cc2)n1-c1ccc(Cl)cc1</smiles>

Pyrrole 43<smiles>COC(=O)c1c(Cc2ccccc2)[n+]([O-])c2ccc(Cl)cc2[n+]1[O-]</smiles>

Quinoxaline 1,4-dioxide 44<smiles>CCCCCCCCCCCCC(N)=O</smiles>

Alkyl sulfinyl amide 45

Figure 11.<smiles>C=CC(C)=C[C@]1(C)SC(=O)C(C)=C1O</smiles>

(5R)-Thiolactomycin 46

Figure 12.

Noto and coworkers as well as Hamada and coworkers have individually reported that TLM has moderate in vitro activity against a broad spectrum of pathogens, like Gram-positive and Gramnegative bacteria including Mycobacterium tuberculosis $(120,123)$. It shows complete inhibition of growth of the virulent strain $M$. tuberculosis Erdmman at $25 \mu \mathrm{g} / \mathrm{mL}$ (114). In rodents, thiolactomycin is well absorbed orally with an $\mathrm{LD}_{50}$ of $1.689 \mathrm{~g} / \mathrm{kg}$ (115). No reports appear to have been published on its efficacy towards $M$. tuberculosis in any animal models. Recently, it has also shown encouraging antimalarial activity, involving inhibition of type II fatty acid biosynthetic pathway in apicoplasts by the research groups of Waller and Morita $(134,140)$. TLM has chemotherapeutic potential, as it is non-toxic to mice and affords significant protection against urinary tract and intraperitoneal bacterial infections (116). Hayashi and coworkers have shown that TLM activity is directed towards type II fatty acid synthases (117). Jones and coworkers (127) confirmed that TLM inhibits type II dissociable fatty acid synthases by using $\left[1-{ }^{14} \mathrm{C}\right]$ acetate labeling 
in pea-leaf chloroplasts. By using of in vivo [1,2${ }^{14} \mathrm{C}$ ]acetate labeling of Mycobacterium smegmatis $(126,127)$, it was shown that it also inhibits the biosynthesis of both fatty acids and mycolic acids, which are the characteristic major 2-alkyl-branched 3-hydroxy fatty acids in Mycobacteria (122, 124, $125,128,129)$. Hence thiolactomycin is also a useful tool for studying and understanding the mechanisms of underlying parasitic infections and infectious diseases.

This new antibiotic has proven to be of considerable interest with its unique thiolactone moiety and because of its broad antibacterial spectrum. The favourable physical and pharmacokinetic properties of thiolactomycin, like low toxicity profile and good activity against several strains of $M$. tuberculosis which are resistant to the other drugs has made it an attractive lead molecule for the development of a drug candidate against the treatment of $M$. tuberculosis.

\section{Mechanism of action}

\section{Thiolactomycin : Bacterial fatty acid synthesis inhibitor}

Fatty acid biosynthesis (FAB) in bacteria, plants and animals is carried out by the ubiquitous fatty acid synthase (FAS) system (130). FAB is an essential metabolic process for prokaryotic organisms and is required for cell viability and growth (131). Targeting this pathway is a rational approach for developing new antibacterial agents $(132,133)$. In the type I system of animals, including humans, FAS is a homodimer of two large polypeptides, each composed of several distinct enzyme domains and is an integral acyl carrier protein (ACP) (134). In the type II system of bacteria, plants and protozoa, the FAS components, including the ACP, exist as discrete proteins (135). The corresponding enzymes of the type I and II FAS are related in structure and function but generally lack overall sequence homology. Large multifunctional proteins termed type I FAS catalyze these essential reactions in eukaryotes (136). In contrast, the bacterial use of multiple enzymes to accomplish the same goal is referred to as type II, or dissociated FAS (137). The bacterial system and proteins bear little homology to the human system and therefore represent a set of attractive target proteins for novel antibacterial development. Since many of today's nosochomial bacterial infections are resistant to several of the available antibiotics, compounds targeting the FAB pathway could fill a serious medical need (138).

A key enzyme responsible for the initiation of bacterial FAB has not yet received attention. $\mathrm{FabH}$, a $\beta$-ketoacyl-acyl carrier protein synthase, is the bacterial condensing enzyme in Gram-positive and Gram-negative bacteria that initiates the cycle by catalyzing the first condensation step between acetyl-CoA and malonyl-ACP $(139,140)$. Mycolic acid, one of the structurally largest fatty acids found in nature, is a vital cell wall component of the human tuberculosis strain of Mycobacterium tuberculosis. The impermeability of this strain to many antibiotics has spawned much research interest into the biosynthesis of mycolic acid with a view to developing novel antibiotics (141).

Biosynthesis of the fatty acyl chain involves two fatty acid synthetic systems, fatty acid synthase I (FAS I), which catalyzes de novo fatty acid synthesis and fatty acid synthase II (FAS II), which consists of monofunctional enzymes that elongate FAS I products into long chain mycolic acid precursors (142). Three enzymes, $\beta$-ketoacylacyl carrier protein synthase (Kas) A and B and the condensing enzyme FabH, have all been identified as FAS II enzymes involved in mycolic acid and fatty acid biosynthesis $(142,143)$. Thiolactomycin inhibits fatty acid synthesis by inhibiting $\mathrm{FabH}$, KasA and KasB. TLM inhibited KasA and KasB displaying $\mathrm{IC}_{50}$ values of $20 \mu \mathrm{M}$ and $90 \mu \mathrm{M}$ respectively (142).

The use of $M$. smegmatis cell extracts confirmed that TLM specially inhibited the mycobacterial acyl-carrier-protein-dependent type II fatty acid synthase (FAS-II), but it did not inhibit the multifunctional type I fatty acid synthase (FASI). Analysis of the in vivo and in vitro data has suggested two separate sites of action for TLM, the $\beta$-ketoacyl carrier protein synthase in FAS-II and the elongation step involved in the synthesis of $\alpha$ mycolates and oxygenated mycolates. In a recent study Kremer and coworkers have shown that the enzymes targeted by TLM are KasA and KasB, which are involved in fatty acid and mycolic acid biosynthesis in M. tuberculosis (114). 


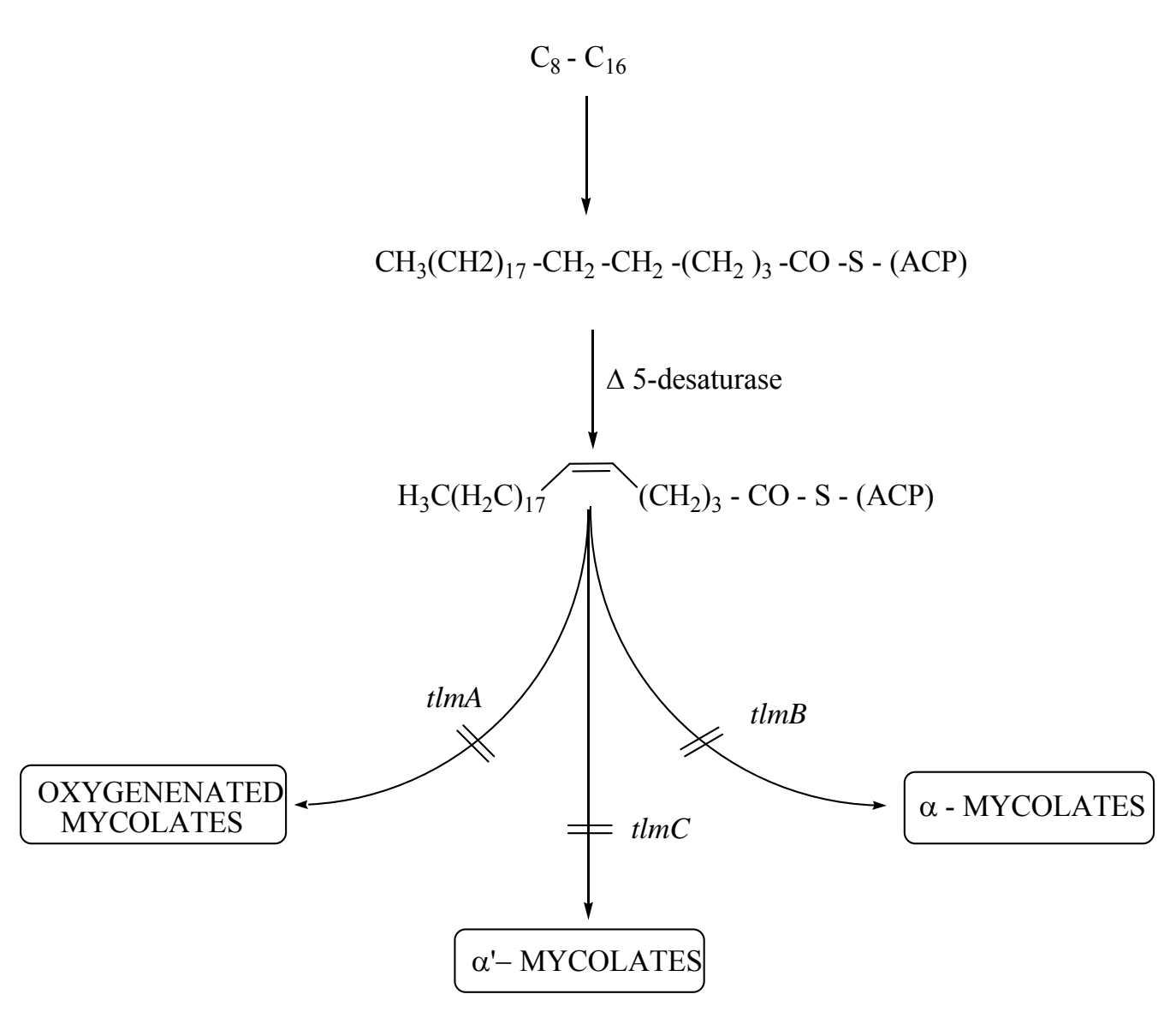

TLM and mycolic acid biogenesis. The sites of action of TLM are represented by $\operatorname{tgmA}$ and $\operatorname{tm} B$. The site of action, tImC is involved in the synthesis of mediumchain length by the FAS-II.

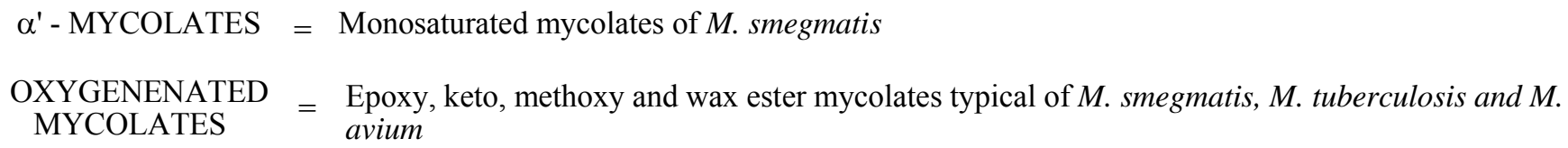

Figure 13.

The in vitro activity of thiolactomycin is substantial against a wide range of strains of $M$. tuberculosis, including those that are resistant to isoniazid, however this is at somewhat higher concentration. However, the above activity is interesting whereas it is insufficient to warrant further progression of thiolactomycin itself as an anti-TB agent $(114,143$, 144). Therefore, new analogues of thiolactomycin needs to be designed and synthesized that could exhibit potential activity against $M$. tuberculosis cultures.

\section{Structure Activity Relationship}

\section{Modifications at C-5}

Minnikin and coworkers have reported various analogues of thiolactomycin at the $\mathrm{C}-5$ position and evaluated their activity against whole cells of Mycobacterium tuberculosis $\mathrm{H} 37 \mathrm{Rv}$ as well as mycolic acid biosynthesis in cell extracts of Mycobacterium smegmatis (145). The analogue with a 5-tetrahydrogeranyl substiuent showed the highest biological activity with an $\mathrm{MIC}_{90}$ of $29 \mu \mathrm{M}$ for M. tuberculosis and $92 \%$ mycolate inhibition in extracts of $M$. smegmatis, as compared to $125 \mu \mathrm{M}$ 
and $54 \%$ respectively, for TLM. Furthermore, the trans-geranyl analogue (47) was inactive against $M$. tuberculosis $\mathrm{H} 37 \mathrm{Rv}$, but the sequential saturation of one or two double bonds (49 or 50) resulted in acceptable activities (Figure 14). Increasing the length of the side chain to trans-trans-farnesyl (48) also gives enhanced activity.

Besra and coworkers have synthesized various thiolactomycin based analogues with biphenyl and acetylene side-chains at the C-5 position of the thiolactone ring $(146,147)$. The compounds 54 and 55, have been derivatized with biphenyl ring, and compounds 56-58 with acetylene side chains. These compounds exhibit moderate in vitro inhibitory activity against the recombinant Mycobacterium tuberculosis $\beta$-ketoacyl-ACP synthase $m t \mathrm{FabH}$ condensing enzymes (Figure 15).

Recently, there was another report on C5 analogues of thiolactomycin (13 biphenyl analogues and two biphenyl mimics) by the same authors. These have been assessed for their $m t F a b H$ and whole cell Mycobacterium bovis BCG activity, respectively (148). Amongst them three analogues (59-61) exhibited a significant enhancement in the in vitro activity against $m t \mathrm{FabH}$ assay. The

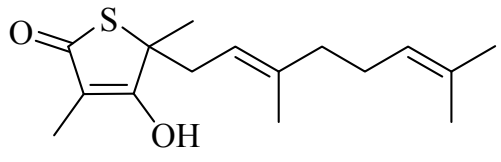

47<smiles>CC(C)=CCCC(C)CCC1(C)SC(=O)C(C)=C1O</smiles>

49

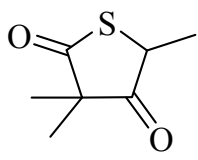

51

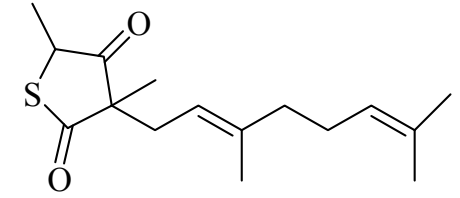

52<smiles>CC(C)=CCC/C(C)=C/CC/C(C)=C/CC1(C)SC(=O)C(C)=C1O</smiles>

48<smiles>CC1=C(O)C(C)(CCC(C)CCCC(C)C)SC1=O</smiles>

50<smiles>CC1=C(O)C(C)(Cc2ccc(C(=O)c3ccccc3)cc2)SC1=O</smiles>

53

Figure 14. 
<smiles>CC1=C(O)C(C)(Cc2ccc(-c3ccc(CO)cc3)cc2)SC1=O</smiles>

54<smiles>CC1=C(O)C(C)(Cc2ccc(-c3ccc(COCc4ccccc4)cc3)cc2)SC1=O</smiles>

55<smiles>CC1=C(O)C(C)(C#Cc2ccccc2)SC1=O</smiles>

56<smiles>CC(=O)c1ccc(C#CC2(C)SC(=O)C(C)=C2O)cc1C</smiles>

Figure 15.<smiles>CC1=C(O)C(C)(Cc2ccc(-c3ccc(C(=O)O)cc3)cc2)SC1=O</smiles><smiles>CC(=O)c1ccc(-c2ccc(CC3(C)SC(=O)C(C)=C3O)cc2)cc1</smiles><smiles>CC1=C(O)C(C)(Cc2ccc(-c3ccc(C(N)=O)cc3)cc2)SC1=O</smiles>

60<smiles>CC1=C(O)C(C)(C#Cc2ccc(C#N)cc2)SC1=O</smiles>

61

Figure 16.

Townsend and co-workers have developed new structural analogues of TLM (68-70) at C-5 position as shown in Figure 18 and they have exhibited weak to moderate activity against Type-I fatty acid synthase (150).

\section{Modifications at C-4}

Design and synthesis of a series of C-4 analogues (71-74) of thiolactomycin has been carried out in this laboratory and the molecules have been evaluated against four different Mycobacterium species namely $M$. tuberculosis H37Rv ATCC 27294, M. tuberculosis clinical isolates (sensitive and resistant), $M$. avium ATCC 49601 and $M$. intracellulare ATCC 13950 (151). The compound 72e, having spacer of eight methylene groups and linked to methyl thioglycolate proved to be is the most active compound with an MIC value 1.0-4.0 $\mu \mathrm{g} / \mathrm{mL}$ against drug sensitive and resistant strain of M. tuberculosis (Figure19).

Based on these findings several new molecules have been designed and prepared in order to understand the SAR. A number of these molecules have good potential for further development and are presently undergoing detailed investigations. 


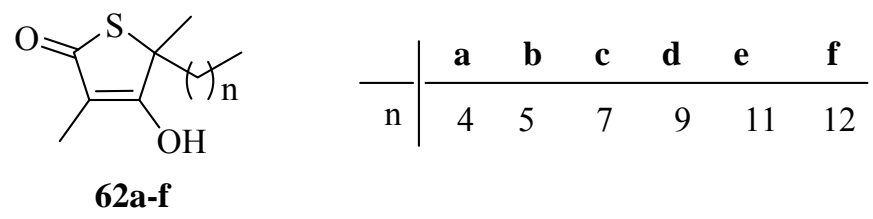

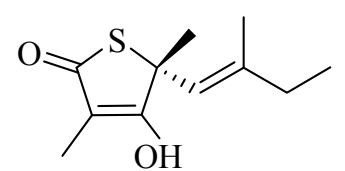

63<smiles>CCC(C)C[C@]1(C)SC(=O)C(C)=C1O</smiles>

65

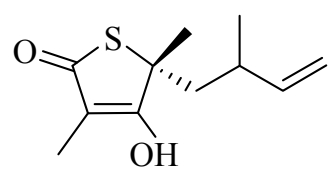

64<smiles>C=C/C=C/C1(C)SC(=O)C(C)=C1O</smiles>

66

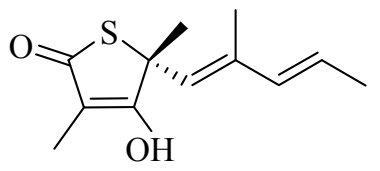

67

Figure 17.

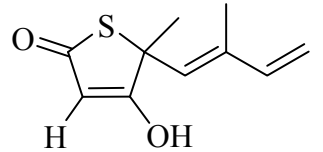

68<smiles>CCCC/C=C/C=C/C1(C)SC(=O)C=C1O</smiles>

69

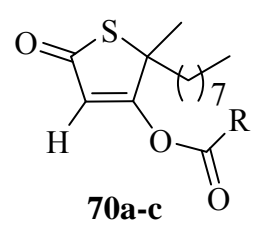

a $\mathrm{R}=-\mathrm{OCH}_{3}$

b $\mathrm{R}=-\mathrm{OCH}_{2} \mathrm{CH}_{3}$

c $\mathrm{R}=-\mathrm{OCH}_{2} \mathrm{CH}=\mathrm{CH}_{2}$

Figure 18.

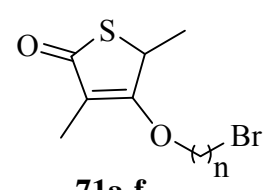

71a-f<smiles>COC(=O)CS[AlH]OC1=C(C)C(=O)SC1C</smiles>

72a-f<smiles>CC1=C(O[14C]N2CCN(C)CC2)C(C)SC1=O</smiles>

73a-f<smiles>CC1=C(O[14C]N2CCOCC2)C(C)SC1=O</smiles>

74a-f

$$
-\mid \begin{array}{cccccc}
\mathbf{a} & \mathbf{b} & \mathbf{c} & \mathbf{d} & \mathbf{e} & \mathbf{f} \\
\hline 3 & 4 & 5 & 6 & 8 & 10
\end{array}
$$

Figure 19. 


\section{Modifications at C-3 and C-5}

Gilbert and coworkers have synthesized a series of analogues of naturally occurring thiolactomycin and evaluated their ability to inhibit the growth of malaria parasite Plasmodium falciparum $(152,153)$. Compounds 75-78 with substitutions at the C-3 and C-5 positions with long chain alkane residues show improved activity against Plasmodium falciparum, blood streams of Trypanosoma brucei and Trypanosoma cruzi amastigotes cultured intracelluarly (Figure 20). This shows that the analogues of thiolactomycin not only have potential in the development of new anti-TB compounds but may be useful as new antimalarial agents.

Sakaya and coworkers synthesized 3-acetyl analogues of thiolactomycin and profiled their activity against live stock pathogens (154). Compounds 79-81 have shown improved activity over thiolactomycin, against Stapylococcus aureus and moderate to comparable activity against Pasteurella multocida (Figure 21).

\section{CONCLUSION}

Inspite of the availability of the BCG vaccine and some chemotherapeutic agents, TB remains a leading infectious killer worldwide. This is mainly due to the lack of new drugs in the market, particularly for effective treatment against the spread of multi drug-resistant (MDR) and extensively drug-resistant (XDR) strains. Therefore, there is an urgent need for the development of new anti-TB drugs with lesser side-effects, improved pharmacokinetic properties to be effective against both the Gram positive and Gram negative bacteria including the resistant strains. More importantly, the newly developed drugs are required to reduce the overall duration of treatment. It is also important to note that while we pursue the development of new drugs based on inhibition of bacterial targets, we need to understand host factors such as immune mechanisms, genetic susceptibility and disease relapse. Therefore, the newer anti-TB compounds need to be developed on the understanding of the molecular mechanisms of drug action and drug resistance.

In recent years, efforts are being made to develop new molecules based on different scaffolds that act on a number of drug targets. Further, the molecular mechanisms and biosynthetic pathways are being unraveled for the already known and newly discovered lead molecules. One of the well established broad spectrum antibacterial drug targets that have been historically very effective is the inhibition of cell wall biosynthesis. Some of the anti-TB agents like isoniazid and ethambutol target different aspects of the cell wall biosynthesis.<smiles>CC1=C(O)C(C)(C(C)(C)C)SC1=O</smiles>

75

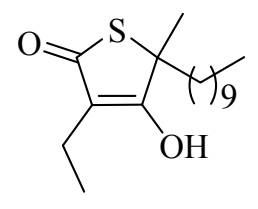

76

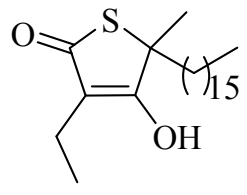

77

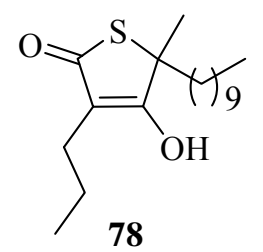

Figure 20.

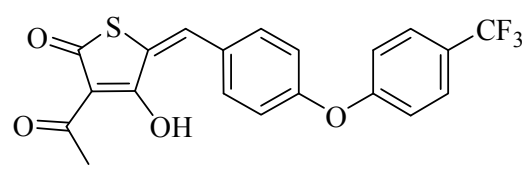

79

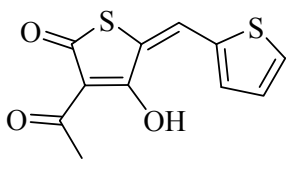

80<smiles>CC(=O)C1=C(O)C(C/C=C(\C)C=CC(C)=[W])SC1=O</smiles>

81

Figure 21. 
Hence, new molecules that are active against cell wall targets could provide valuable therapeutic options for the therapeutic application including drug resistance. Thiolactomycin, which is a natural product, inhibits bacterial as well as plant type II fatty acid synthases (FAS-II), which provide essential building blocks for the bacterial cell wall. Thiolactomycin is believed to exert its overall effect by inhibition of the $\beta$-keto acyl-ACP-synthases (Kas), key condensing enzymes involved in the chain elongation in FAS-II. Therefore, developing structurally modified compounds based on

\section{REFERENCES}

[1]. Enarson DA, Chretien J. Epidemiology of respiratory infectious diseases. Curr Opin Pulm Med 5: 128-135, 1999.

[2]. World Health Organisation. Tuberculosis Fact Sheet No. 104, 2000. http://www.who.int/inffs/en/fact104.html/.

[3]. Moran N, WHO issues another gloomy tuberculosis. report. Nat Med. 2: 377, 1996.

[4]. Snider DE Jr, Raviglione M, Kochi A. Global burden of tuberculosis. In B.R. Bloom (ed.), Tuberculosis: pathogenesis, protection, and control. Am. Soc. Microbiol 2: 3-11, 1994, Washington, DC.

[5]. Dye C, Scheele S, Dolin P, Pathania V, Raviglione MC. Global Burden of Tuberculosis. J Am Med Assoc 282: 677, 1999.

[6]. Farmer P, Bayona J, Beccera M, Furin J, Henry C, Hiarr H, Kim JY, Mimic C, Nardell E, Shin S. The dilemma of MDRTB in the global era. Int $\mathrm{J}$ Tuberc Lung Dis 2: 869-876, 1998.

[7]. Dony JF, Ahmad J, Khen TY. Epidemiology of tuberculosis and leprosy, Sabah, Malaysia. Tuberculosis 84: 8-18, 2004.

[8]. Koch $\mathrm{R}$ Die aetiologie der tuberkulose. Die Aetiologie der 19: 221-230, 1882.

[9]. Turenne CY, Tschetter L, Wolfe J, Kabani A. Necessity of quality-controlled 16S rRNAgene sequence databases: identifying nontuberculous Mycobacterium species. J Clin Microbiol 39: 3637-3648, 2001. http://www.ridom rdna.de/mycobacteria.

[10]. Minnikin DE. Lipids: complex lipids, their chemistry, biosynthesis and roles. In: The Biology of the Mycobacteria (Ratledge C. and Stanford J. Eds.), Vol. 1, page 95-184, 1982. Academic Press Inc. Ltd., London.

[11]. Walters SB, Dubnau E, Kolesnikova I, Laval F, Daffe M, Smith I. The Mycobacterium thiolactomycin structure as well as the thiolactone ring could provide novel anti-TB drugs. Based on its potential as an attractive lead molecule, efforts are being made by many research groups including our laboratory to structurally modify this natural product for the development of new anti-TB agents.

\section{ACKNOWLEDGMENT}

The authors (SA and MSM) are thankful to CSIR, New Delhi for the award of research fellowship.

tuberculosis PhoPR two-component system regulates genes essential for virulence and complex lipid biosynthesis. Molecular Microbiol. 60: 312-330, 2006.

[12]. Slayden RA, and Barry CE. The role of KasA andKasB in the biosynthesis of meromycolic acids and isoniazid resistance in Mycobacterium tuberculosis. Tuberculosis 82: 149-160, 2002.

[13]. Chatterjee D, Khoo KH, McNeil MR, Dell A, Morris HR, Brennan PJ. Structural definition of the non-reducing termini of mannose-capped LAM from Mycobacterium tuberculosis through selective enzymatic degradation and fast atom bombardment- mass spectrometry. Glycobiology, 3: 497-500, 1993.

[14]. Cole ST, Brosch R, Parkhill J, Garnier T, Churcher C, Harris D, Gordon SV, Eiglmeier K, Gas S, Barry C E, Tekaia F, Badcock K, Basham D, Brown D, Chillingworth T, Connor R, Davies R, Devlin K, Feltwell T, Gentles S, Hamlin N, Holroyd S, Hornsby T, Jagels K, Krough A, McLean J, Moule S, Murphy L, Oliver K, Osborne J, Quail MA, Rajandream MA., Rogers J, Rutter S, Seeger K, Skelton J, Squares R, Squares S, Sulston JE, Taylor K Whitehead S, Barrell BG. Deciphering the biology of Mycobacterium tuberculosis from the complete genome sequence Nature 393: 537-544, 1998.

[15]. http:// www. doe-mbi.ucla.edu/TB/

[16]. Clatworthy AE, Pierson E, Hung DT. Targeting virulence: a new paradigm for antimicrobial therapy. Nat Chem Biol 3: 541-548, 2007.

[17]. World Health Organization. Strategic framework to decrease the burden of TB/HIV documents WHO/CDS/ TB2002, 296, WHO/HIVAIDS/2002, 2. Geneva, Switzerland: World Health Organization, 2002. 
[18]. Espinal MA. The global situation of MDR-TB. Tuberculosis 83: 44-51, 2003.

[19]. Amalio T, Michael I, Drug-Resistant Tuberculosis: What Do We Do Now? Drugs 59: 171-179, 2000.

[20]. Pablos-Mendez A, Raviglione MC, Laszlo A, Binkin N, Rieder HL, Bustreo F, Cohn DL, Lambregts-van Weezenbeek CS, Kim SJ, Chaulet P, Nunn P. Global Surveillance for Antituberculosis-Drug Resistance 1994-1997. N Engl J Med 338: 1641-1649, 1998.

[21]. Cohn DL, Bustreo F, Raviglione MC. Drugresistant tuberculosis: review of the worldwide situation and the WHO/IUATLD Global Surveillance Project. Clin Infect Dis, 24: S121S130, 1997

[22]. Cole ST, Phillip W, Heym B. Mechanisms of drug resistance in Mycobacterium tuberculosis. Curr Top Microbiol Immunol, 215: 49-69, 1996.

[23]. Barry CE III. New horizons in the treatment of tuberculosis. Biochem Pharmacol 54: 11651172, 1997.

[24]. Barry CE, Slayden RA, Sampson AE, Lee RE. Use of genomics and combinatorial chemistry in the development of new antimycobacterial drugs. Biochem Pharmacol 59, 221-231, 2000.

[25]. Tomasz A. Multiple-antibiotic-resistant pathogenic bacteria. A report on the Rockefeller University Workshop. N Eng J Med 330: 12471251, 1994.

[26]. Global Tuberculosis Control: Surveillance, Planning, Financing WHO REPORT 2008, 5154.

[27]. Davidson PT, Le HQ. Drug Treatment of Tuberculosis - 1992. Drugs. 43: 651-673, 1992.

[28]. Tillotson GS. Quinolones: structure-activity relationships and future predictions. J Med Microbiol 44: 320-324, 1996.

[29]. Grange J. Antimycobacterial agents. In: O'Grady F, Lambert H P, Finch RG, Greenwood D editors. Antibiotic and chemotherapy, 7th edition. Edinburg: Churchil Livingstone 449512, 1997.

[30]. Greenwood D, Historical introduction. In: O'Grady F, Lambert HP, Finch RG, Greenwood D. editors. Antibiotic and chemotherapy, 7th edition. Edinburg: Churchill Livingston 2-9, 1997.

[31]. Finken M, Kirschner P, Meier A, Wrede A, Bottger EC. Molecular basis of streptomycin resistance in Mycobacterium tuberculosis: alterations of the ribosomal protein S12 gene and point mutations within a functional $16 \mathrm{~S}$ ribosomal RNA pseudoknot. Mol Microbial 9: 1239-1246, 1993.
[32]. Zhang Y, Heym B, Allen B, Young D, Cole S. The catalase-peroxidase gene and isoniazid resistance of Mycobacterium tuberculosis. Nature 358: 591-593, 1992.

[33]. Zhang Y, Garbe T, Young D. Transformation with katG restores isoniazid-sensitivity in Mycobacterium tuberculosis isolates resistant to a range of drug concentrations. Mol Microbiol 8 521-524, 1993.

[34]. Heym B, Alzari PM, Honore N, Cole ST. Missense mutations in the catalase-peroxidase gene, katG, are associated with isoniazid resistance in Mycobacterium tuberculosis. Mol Microbiol 15: 235-245, 1995.

[35]. Mdluli K, Slayden RA, Zhu Y, Ramaswamy S, Pan X, Mead D, Crane DD, Musser JM, Barry CE III. Inhibition of Mycobacterium tuberculosis beta-ketoacyl ACP synthetase by isoniazid. Science 280: 1607-1610, 1998.

[36]. The name rifamycin (originally rifomycin) is derived from the title of a French movie, Rififi, popular at the time of the antibiotic's discovery. Sensi, P. History of the development of rifamycin. Rev Infect Dis 5: S402-S406, 1983.

[37]. Rinehart KL Jr, Shields LS. Fortschr Chemistry of the ansamycin antibiotics. Chem. Org Naturs., 33: 231-307, 1976.

[38]. Wehrli W. Ansamycins: Chemistry, biosynthesis and biological activity. Top Curr Chem 72: 2149, 1977.

[39]. Prelog V, Oppolzer W. Rifamycins. 4. Ansamycins, a novel class of microbial metabolism products. Helv Chim Acta 56: 22792287, 1973.

[40]. Parneti F, Lancini G. Rifamycins. In: O’Grady F, Lambert HP, Finch RG, Greenwood D, editors. Antibiotic and chemotherapy, 7th edition. Edinburg: Churchill Livingston 453-459, 1997.

[41]. Gale EF, Cundliffe E, Reynolds PE, Richmond $\mathrm{MH}$, Waring MJ. The molecular basic of antibiotic action, 2nd edition. London: John Wiley and Sons 1981.

[42]. Rastogi N, Labrousse V. Extracellular and intracellular activities of clarithromycin used alone and in association with ethambutol and rifampin against Mycobacterium avium complex. Antimicrob Agents Chemother 35: 462-470, 1991.

[43]. Inderlied $\mathrm{CB}$, Barbara-Burnham $\mathrm{L}, \mathrm{Wu} \mathrm{M}$, Young LS, Bermudez LE. Activities of the benzoxazinorifamycin KRM 1648 and ethambutol against Mycobacterium avium complex in vitro and in macrophages. Antimicrob Agents Chemother 38: 1838-1843, 1994. 
[44]. Mikusova K, Slayeden RA, Besra GS, Brennan PJ. Biogenesis of the mycobacterial cell wall and the site of action of ethambutol. Antimicrob Agents Chemother 39: 2484-2489, 1995.

[45]. Tripathi RP, Tewari N, Dwivedi N, Tiwari VK. Fighting tuberculosis: An old disease with new challenges. Medicinal Research Reviews 25: 93131, 2005.

[46]. Scorpio A, Zhang Y. Mutations in pncA, a gene encoding pyrazinamidase/nicotinamidase, cause resistance to the antituberculous drug pyrazinamide in tubercle bacillus. Nat Med 2: 662-667, 1996.

[47]. McCune RM, Feldman FM, McDermat W. Microbial persistence II. Characterstics of the sterile state of tubercular bacilli. J Exp Med 123: 469-486, 1966.

[48]. Konno K, Feldmann FM, Mc Dermott W. Pyrazinamide susceptibility and amidase activity of tubercle bacilli. Am Rev Resp Dis 95: 461469, 1967.

[49]. Mc Dermott W, Tompsett R. Pyrazinamide sterilizing activity in vitro against semi-dormant Mycobacterium tuberculosis bacterial populations. Am Rev Tuberc, 70: 748-754, 1954.

[50]. Center for Disease Control. "Emergence of Mycobacterium tuberculosis with Extensive Resistance to Second-Line Drugs - Worldwide, 2000-2004". MMWR Weekly 55: 301-305, 2006.

[51]. Edson RS, Terrell CL. The aminoglycosides. Mayo Clin Proc 74: 519-528, 1999.

[52]. Garrod LP, Lambert HP, O'Grady F. Antibiotic and Chemotherapy. Churchill Livingstone, Edinburgh. 131-131, 1981.

[53]. Kanamycin. Tuberculosis 88: 117-118, 2008.

[54]. Skinner RH, Cundliffe E. Resistance to the antibiotics viomycin and capreomycin in the Streptomyces species which produce them. J Gen Microbiol 120: 95-104, 1980.

[55]. Le Conte P, Le Gallou F, Potel G, Struillou L, Baron D, Drugeon HB. Pharmacokinetics, toxicity, and efficacy of liposomal capreomycin in disseminated Mycobacterium avium beige mouse model. Antimicrob Agents Chemother 38: 2695-2701, 1994.

[56]. Da Silva AD, De Almeida MV, De Souza MVN, Couri MRC. Biological activity and synthetic methodologies for the preparation of fluoroquinolones, a class of potent antibacterial agents. Curr Med Chem 10: 21-39, 2003.

[57]. Wolfson JS, Hooper DC. The fluoroquinolones: Structures mechanism of action and resistance and spectra of activity in vitro.Antimicrob Agents Chemother :28: 581-586, 1985.
[58]. Lowther J, Bryskier A. Fluoroquinolones and tuberculosis. Curr. Med Res Opin 11: 233-258, 2002.

[59]. Quemard A, Laneelle G, Lacave C. Mycolic acid synthesis: a target for ethionamide in mycobacteria? Antimicrob Agents Chemother 36: 1316-1321, 1992.

[60]. Otten H. Antituberculosis drugs. Handbook of experimental pharmacology Berlin: SpringerVerlog 44: 158-166, 1988.

[61]. David HL, Takayama K, Goldman DS. Susceptibility of mycobacterial D-alanyl-Dalanine synthetase to D-cycloserine. Am Rev Resp Dis 100: 579-581, 1969.

[62]. Otten H. Experimental evalution of efficacy VII. Cycloserine (CS) and terizidone (TZ) In: Bartman K, editor. Antituberculosis drugs. Handbook of experimental pharmacology, Vol 44, Berlin: Springer-Verlog, 158-166, 1997.

[63]. Lehmann J. Para-aminosalicylic acid in the treatment of tuberculosis. Lancet 247: 15-16, 1946.

[64]. Zuckerman JM. The newer macrolides: azithromycin and clarithromycin Infect Dis Clin of North America, 14: 449-462, 2000.

[65]. Rieder HL, Arnadottir T, Trebucq A, Enarson DA. Tuberculosis treatment: dangerous regimens?. Int J Tuberc Lung Dis 5: 1-3, 2001.

[66]. Nunn P, Porter J, Winstanley P. Thiacetazoneavoid like poison or use with care? Trans R Soc Trop Med Hyg 87: 578-582, 1993.

[67]. Amaral L, Viveiros M, Molnar J. Antimicrobial activity of phenothiazines. In Vivo. 18: 725-731, 2004.

[68]. Mitscher LA, Baker W. Tuberculosis: A search for novel therapy starting with natural products. Med Res Rev 18: 363-374, 1998.

[69]. Stover CK, Warrener P, VanDevanter DR, Sherman DR, Arain TM, Langhorne MH, Anderson SW, Towell JA, Yuan Y, McMurray DN, Kreiswirth BN, Barry CE, Baker WR A small-molecule nitroimidazopyran drug candidate for the treatment of tuberculosis. Nature 405: 962-966, 2000.

[70]. Ashtekar DR, Costa-Perira R, Nagrajan K, Vishvanathan $\mathrm{N}$, Bhatt $\mathrm{AD}$, Rittel $\mathrm{W}$. In vitro and in vivo activities of the nitroimidazole CGI 17341 against Mycobacterium tuberculosis. Antimicrob Agents Chemother 37: 183-186, 1993.

[71]. Tucker JA, Allwine DA, Grega KC, Barbachyn MR, Klock JL, Adamski I, Brickner SJ, Hutchinson DK, Ford CW, Zurenko GE, Conradi A, Buston PS, Jensen RM. Piperazinyl oxazolidinone antibacterial agents containing a 
pyridine, diazene, or triazene heteroaromatic ring. J Med Chem 41: 3727-3735, 1998.

[72]. Brickner SJ, Hutchinson DK, Barbachyn MR, Manninen PR, Ulanowicz DA, Garmon A, Grega KC, Hendges SK, Toops DS, Ford CW, Zurenko GE. Synthesis and antibacterial activity of U100592 and U-100766, two oxazolidinone antibacterial agents for the potential treatment of multidrug-resistant gram-positive bacterial infections J Med Chem 39: 673-679, 1996.

[73]. Eustice DC, Feldman PA, Zajac I, Slee AM. Mechanism of action of DuP 721: inhibition of an early event during initiation of protein synthesis. Antimicrob Agents Chemother 32: 1218-1222, 1988.

[74]. Field SK, Cowie RL. Treatment of Mycobacterium avium-intracellulare complex Lung Disease With a Macrolide, Ethambutol, and Clofazimine Chest 124: 1482-1486, 2003.

[75]. Kamal A, Babu AH, Ramana AV, Sinha R, Yadav JS, Arora SK. Antitubercular agents. Part 1: Synthesis of phthalimido- and naphthalimidolinked phenazines as new prototypeantitubercular agents. Bioorg. Med. Chem. Lett. 15: 1923-1926, 2005.

[76]. Tangalapally RP, Yendapally R, Lee RE, Lenaerts AJM, Lee RE. Synthesis and Evaluation of Cyclic Secondary Amine Substituted Phenyl and Benzyl Nitrofuranyl Amides as Novel Antituberculosis Agents. J Med Chem 48: 8261-8269, 2005.

[77]. Bakkestuen AK, Gundersen LL, Langli G, Liu F, Nolsoe JM. 9-Benzylpurines with inhibitory activity against mycobacterium tuberculosis. Bioorg Med Chem Lett 10: 1207-1210, 2000.

[78]. Gundersen LL, Meyer JN, Spilsberg B. Synthesis and antimycobacterial activity of 6arylpurines: The requirements for the $N-9$ substituent in active antimycobacterial purines. J Med Chem 45, 1383-1386, 2002.

[79]. Scozzafava A, Mastrolorenzo A, Supuran CT. Antimycobacterial activity of 9-sulfonylated sulfenylated-6-mercaptopurine derivatives. Bioorg Med Chem Lett 11: 1675-1678, 2001.

[80]. Shindikar AV, Viswanathan CL. Novel fluoroquinolones: Design, synthesis, and in vivo activity in mice against mycobacterium tuberculosis H37Rv. Bioorg Med Chem Lett 15: 1803-1806, 2005.

[81]. Andries K, Verhasselt P, Guillemont J, Gohlmann HWH, Neefs J-M, Winkler H, Gestel JV, Timmerman P, Zhu M, Lee E, Williams P, de Chaffoy D, Huitric E, Hoffner S, Cambau E, Truffot-Pernot C, Lounis N, Jarlier V. A diarylquinoline drug active on the ATP synthase of mycobacterium tuberculosis. Science 307: 223-227, 2005.

[82]. Girard Y, Atkinson JG, Rokach J. A new synthesis of 1,2,4-benzothiadiazines and a selective preparation of $O$ aminobenzenesulphonamides. J Chem Soc Perkin Trans 1 1043-1047, 1979

[83]. Reddy AVN, Kamal A, Sattur PB. Synthesis and biological activity of 3-pyrazolyl-4-substituted2H-1,2,4-benzothiadiazine 1,1-dioxide. Indian J Chem 24B 1295-1297, 1985.

[84]. NCCLS. Susceptibility Testing of Mycobacteria, Nocardia, and Other Aerobic Actinomycetes; Tentative Standard, 2nd ed.; NCCLS document M24-T2 [ISBN 1-56238-423-6]. NCCLS, 960 West Valley Road, Suite1400, Wayne, PA 19087-1898, USA, 2000.

[85]. Dolezal M, Jampilek J, Osicka Z, Kunes J, Buchta V, Vichova P. Substituted 5aroylpyrazine-2-carboxylic acid derivatives: synthesis and biological activity Il Farmaco, 58: 1105-1111, 2003.

[86]. Cocco MT, Congiu C, Onnis V, Pusceddu MC, Schivo ML, Logu A. Synthesis and antimycobacterial activity of some isonicotinoylhydrazones. Eur J Med Chem 34: 1071-1076, 1999.

[87]. Kamal A, Reddy KS, Ahmed SK, Khan MNA, Sinha RK, Yadav JS, Arora SK. Anti-tubercular agents. Part 3: Benzothiadiazines as a novel scaffold for anti-mycobacterim activiy.Bioorg Med Chem 14: 650-658, 2006.

[88]. Kamal A, Ahmed SK, Reddy KS, Khan MNA, Shetty RVCRNC, Siddhardha B, Murthy USN, Khan IA, Kumar M, Sharma S, Ram AB. Antitubercular agents. Part IV: Synthesis and antimycobacterial evaluation of nitroheterocyclic-based 1,2,4-benzothiadiazines. Bioorg Med Chem Lett 17: 5419-5422, 2007.

[89]. Deidda D, Lampis G, Fioravanti R, Biava M, Porretta G, Zanetti S, Pompei R. Bactericidal activities of the pyrrole derivative BM212 against multidrug-resistant and intramacrophagic mycobacterium tuberculosis strains. Antimicrob Agents Chemother 42: 3035-3037, 1998.

[90]. Jaso A, Zarrana B, Aldana I, Monge A. Synthesis of new quinoxaline-2-carboxylate 1,4dioxide derivatives as anti-mycobacterium tuberculosis agents. J Med Chem 48: 2019-2025, 2005.

[91]. Jones PB, Parrish NM, Houston TA, Stapon A, Bansal NP, Dick JD, Townsend C A. A new class of antituberculosis agents. J Med Chem 43: 3304-3314, 2000. 
[92]. Koul A, Herget T, Kleb B, Ullrich A. Interplay between mycobacteria and host signalling pathways. Nat Rev Microbiol 2: 189-202, 2004.

[93]. Scherr N, Honnappa S, Kunz G, Mueller P, Jayachandran R, Winkler F, Pieters J, Steinmetz M.O. Structural basis for the specific inhibition of protein kinase $\mathrm{G}$, a virulence factor of Mycobacterium tuberculosis. Proc Natl Acad Sci U S A 104: 12151-12156, 2007.

[94]. Soellner MB, Rawls KA, Grundner C, Alber T, Ellman JA. Fragment-based substrate activity screening method for the identification of potent inhibitors of the Mycobacterium tuberculosis phosphatase PtpB. J Am Chem Soc 129, 96139615, 2007.

[95]. Hilliard JJ, Goldschmidt RM, Licata L, Baum EZ, Bush K. Multiple Mechanisms of Action for Inhibitors of Histidine Protein Kinases from Bacterial Two-Component Systems. Antimicrob Agents Chemother 43: 1693-1699, 1998.

[96]. Stephenson K, Yamaguchi Y, Hoch JA. The Mechanism of Action of Inhibitors of Bacterial Two-component Signal Transduction Systems. J Biol Chem 275: 38900-38904, 2000.

[97]. Matsushita M, Janda KD. Histidine kinases as targets for new antimicrobial agents. Bioorg Med Chem 10: 855-867, 2002.

[98]. Stephenson K, Hoch JA. Developing Inhibitors to Selectively Target Two Component and Phosphorelay Signal Transduction Systems of Pathogenic Microorganisms. Curr Med Chem 11: 765-773, 2004.

[99]. Matyk J, Waisser K, Drazkova K, Kunes J, Klimesova V, Palat K Jr.; Kaustova J. Heterocyclic isosters of antimycobacterial salicylanilides. Farmaco Ed Sci 60: 399-408, 2005.

[100]. Waisser K, Matyk J, Divisova H, Husakova P, Kunes J, Klimesova V, Kaustova J, Mollmann U, Dahse HM, Miko M. The Oriented Development of Antituberculotics: Salicylanilides. Arch Pharm, 339: 616-620, 2006.

[101]. Hlasta DJ, Demers JP, Foleno BD, Fraga-Spano S, Guan J, Hilligard JJ, Macielag MJ, Ohemeng KA, Sheppard CM, Sui Z, Webb GC, WeidnerWells MA, Werblood H, Barrett JF. Novel inhibitors of bacterial two-component systems with gram positive antibacterial activity: Pharmacophore identification based on the screening hit closantel. Bioorg Med Chem Lett 8: 1923-1928, 1998.

[102]. Macielag MJ, Demers JP, Fraga-Spano SA, Hlasta DJ, Johnson SG, Kanojia RM, Russell RK, Sui Z, Weidner-Wells MA, Werblood H, Foleno BD, Goldschmidt RM, Loeloff MJ,
Webb GC, Barrett JF. Substituted Salicylanilides as Inhibitors of Two-Component Regulatory Systems in Bacteria. J Med Chem 41: 29392945, 1998.

[103]. Rickman L, Saldanha JW, Hunt DM, Hoar N, Colston MJ, Millar JB, Buxton RS. A twocomponent signal transduction system with a PAS domain-containing sensor is required for virulence of Mycobacterium tuberculosis in mice. Biochem Biophys Res Commun 314: 259267, 2004.

[104]. Av-Gay Y, Everett M. The eukaryotic-like $\mathrm{Ser} / \mathrm{Thr}$ protein kinases of Mycobacterium tuberculosis. Trends Microbiol 8: 238-244, 2000.

[105]. Greenstein AE, Grundner C, Echols N, Gay LM, Lombana TN, Miecskowski CA, Pullen KE, Sung P, Alber TJ. Mol Microbiol Biotechnol 9: 167-181, 2005.

[106]. Peirs P, De Wit L, Braibant M, Huygen K, Content JA. Serine/Threonine Protein Kinase from Mycobacterium tuberculosis. Eur J Biochem, 244: 604-612, 1997.

[107]. Walburger A, Koul A, Ferrari G, Nguyen L, Prescianotto-Baschong C, Huygen K, Klebl B, Thompson C, Bacher G, Pieters J. Protein Kinase $G$ from Pathogenic Mycobacteria Promotes Survival Within Macrophages. Science, 304: 1800-1804, 2004.

[108]. Koul A, Klebl B, Mueller G, Missio A, Schwab W, Hafenbradl D, Neumann L, Sommer M.-N, Mueller S, Hoppe E, Freisleben A, Backes A, Hartung C, Felber B, Zech B, Engkvist O, Keri G, Oerfi L, Banhegyi P, Greff Z, Horvath Z, Varga Z, Marko P, Pato J, Szabadkai I, Szekelyhidi Z, Waczek F. Patent WO 2005 023818; see Chem. Abstr. 2005, 142, 316820.

[109]. Pato J, Keri G, Orfi L, Waczeck F, Horvath Z, Banhegyi P, Szabadkai I, Marosfaldi J, Hegymegi-Barkonyi B, Szekelyhidi Z, Greff Z, Choidas A, Bacher G, Missio A, Koul A, Patent U.S. 2004 171603; see Chem. Abstr. 2004, 141, 236625p.

[110]. Ortega MA, Montoya ME, Jaso A, Zarranz B, Tirapu I, Aldana I, Monge A. Antimycobacterial activity of new quinoxaline-2-carbonitrile and quinoxaline-2-carbonitrile 1,4-di-N-oxide derivatives. Pharmazie 56: 205-207, 2001.

[111]. Zarranz B, Jaso A, Aldana I, Monge A. Synthesis and antimycobacterial activity of new quinoxaline-2-carboxamide 1,4-di- $\mathrm{N}$-Oxide derivatives. Bioorg Med Chem 11: 2149-2156, 2003.

[112]. Zanetti S, Sechi LA, Molicotti P, Cannas S, Bua A, Deriu A, Carta A, Paglietti G. In vitro activity of new quinoxalin 1,4-dioxide derivatives 
against strains of Mycobacterium tuberculosis and other mycobacteria. Int $\mathrm{J}$ Antimicrob Agents, 25: 179-181, 2005.

[113]. Heath RJ, Rock CO. Fatty acid biosynthesis as a target for novel antibacterials. Curr Opin InVest Drugs 5: 146-153, 2004.

[114]. Slayden RA, Lee RE, Armour JW, Cooper AM, Orme IM, Brennan PJ, Besra GS. Antimycobacterial action of thiolactomycin: An inhibitor of fatty acid and mycolic acid synthesis. Antimicrob Agents Chemother 40: 2813-2819, 1996.

[115]. Noto T, Miyakawa S, Oishi H, Endo H, Okazaki $\mathrm{H}$. Thiolactomycin, a new antibiotic. III. In vitro antibacterial activity. J Antibiot (Tokyo) 35: 401-410, 1982.

[116]. Miyakawa S, Suzuki K, Noto T, Harada Y, Okazaki H. Thiolactomycin, a new antibiotic. IV. Biological properties and chemotherapeutic activity in mice. J Antibiot (Tokyo) 35: 411-419, 1982.

[117]. Hayashi T, Yamamoto O, Sasaki H, Kawaguchi A, Okazaki H. Mechanism of action of the antibiotic thiolactomycin inhibition of fatty acid synthesis of Escherichia coli. Biochem Biophys Res Commun 115: 1108-1113, 1983.

[118]. Heath RJ, White SW, Rock CO. Lipid biosynthesis as a target for antimicrobial agents. Prog Lipid Res 40: 467-497, 2001.

[119]. Tsay JT, Rock CO, Jackowski S. Overproduction of beta-ketoacyl-acyl carrier protein synthase I imparts thiolactomycin resistance to Escherichia coli K-12. J Bacteriology 174: 508-513, 1992.

[120]. Oishi H, Noto T, Sasaki H, Suzuki K, Hayashi T, Okazaki H, Ando K, Sawada M. Thiolactomycin, a new antibiotic. I. Taxonomy of the producing organism, fermentation and biological properties. J Antibiot (Tokyo) 35: 391-395, 1982.

[121]. Sasaki H, Oishi H, Hayashi T, Noto T, Ando K, Sawada M. Thiolactomycin, A new antibiotic II. Structure elucidation. J Antibiot (Tokyo) 35: 396-400, 1982.

[122]. Nishida I, Kawaguchi A, Yamada M. Effect of thiolactomycin on the individual enzymes of the fatty acid synthase system in Escherichia coli. J Bio Chem 99: 1447-1454, 1986.

[123]. Hamada S, Fujiwara T, Shimauchi H, Ogawa T, Nishihara $T$, Koga $T$, Nehashi $T$, Matsuno $T$. Antimicrobial activities of thiolactomycin against gram-negative anaerobes associated with periodontal disease. Oral Microbiol Immunol 5: 340-345, 1990.

[124]. Choi KH, Kremer L, Besra GS Rock CO. Identification and substrate specificity of betaketoacyl (acyl carrier protein) synthase III
$(\mathrm{mtFabH})$ from mycobacterim tuberculosis. J Biol Chem 275: 28201-28207, 2000.

[125]. Hayashi T, Yamamoto O, Sasaki H, Okazaki H, Kawaguchi A. Inhibition of fatty acid syntheis by the antibiotic thiolactomycin. J Antibiot 37: 1456-1461, 1984.

[126]. Jones AL, Dancer JE, Harwood JL. The effect of thiolactomycin analogues on fatty acid synthesis in peas. Biochem Soc Trans 22, 258S.

[127]. Jones AL, Herbert D, Rutter AJ, Dancer JE, Harwood JL. Novel inhibitors of the condensing enzymes of the type II fatty acid synthase of pea (pisum sativum). Biochem J 347: 205-209, 2000.

[128]. Minnikin DE, Minnikin SM, Goodfellow M, Stanford JL. The mycolic acids of mycobacterium chelonei. J Gen Microbiol 128: 817-822, 1982.

[129]. Jackowski S, Zhang YM, Price AC, White SW, Rock CO. A missense mutation in the fabB ( $\beta$ ketoacyl-acyl carrier protein synthase I) gene confers thiolactomycin resistance to Escherichia coli. Antimicrob Agents Chemother 46: 12461252, 2002.

[130]. Jayakumar A, Tai MH, Huang WY, Al Feel W, Hsu M, Abu-Elheiga L, Chirala SS, Wakil SJ, Human fatty acid synthase: Properties and molecular cloning. Proc Natl Acad Sci USA 92: 8695-8699, 1995.

[131]. Chirala SS, Huang WY, Jayakumar A, Sakai K, Wakil SJ. Human fatty acid synthase: Role of interdomain in the formation of catalytically active synthase dimmer. Proc Natl Acad Sci U S A 98: 3104-3108, 2001.

[132]. Payne DJ, Warren PV, Holmes DJ, Ji Y, Lonsdale JT. Bacterial fatty-acid biosynthesis: A genomics-driven target for antibacterial drug discovery. Drug Discovery Today 6: 537-544, 2001.

[133]. Khandekar SS, Daines RA, Lonsdale JT. Bacterial $\quad \beta$-ketoacyl-Acyl Carrier Protein Synthases as Targets for Antibacterial Agents. Curr. Protein and Peptide Sci. 4: 21-29, 2003.

[134]. Heath RJ. Bacterial fatty-acid biosynthesis: An antibacterial drug target waiting to be exploited Drug Discovery Today 6: 715, 2001.

[135]. Chirala SS, Huang WY, Jayakumar A, Sakai K, Wakil SJ. Animal fatty acid synthase: Functional mapping and cloning and expression of the domain I constituent activities. Proc Natl Acad Sci USA 94: 5588-5593, 1997.

[136]. Cronan JE Jr, Rock CO. Biosynthesis of membrane lipids. In: FC. Neidhardt et al Editors Escherichia coli and Salmonella typhimurium: Cellular and Molecular Biology (Second Ed.) 
American Society for Microbiology Washington DC 612-636, 1996.

[137]. Clough RC, Matthis AL, Barnum SR, Jaworski JG. Purification and characterization of 3ketoacyl-acyl carrier protein synthase III from spinach. A condensing enzyme utilizing acetylcoenzyme A to initiate fatty acid synthesis. J Biol Chem 267: 20992-20998, 1992.

[138]. Waller RF, Keeling PJ, Donald RG, Striepen B, Handman E, Lang-Unnasch N, Cowman AF, Besra GS, Roos DS, McFadden GI. Nuclearencoded proteins target to the plastid in Toxoplasma gondii and Plasmodium falciparum. Proc Natl Acad Sci USA 95: 12352-12357, 1998.

[139]. Qiu X, Janson CA, Court RI, Smyth MG, Payne DJ, Abdel-Meguid SS. Molecular basis for triclosan activity involves a flipping loop in the active site. Protein Sci 8: 2529-2532, 1999.

[140]. Nie Z, Perretta C, Lu J, Su Y, Margosiak S, Gajiwala KS, Cortez J, Nikulin V, Yager KM, Appelt K, Chu S. Structure-based design, synthesis, and study of potent inhibitors of $\beta$ ketoacyl-acyl carrier protein synthase III as potential antimicrobial agents. J Med Chem 48: 1596-1609, 2005.

[141]. Banerjee A, Dubnau E, Quemard A, Balasubramanian V, Sun Um K, Wilson T, Collins D, de Lisle G, Jacobs WR. A gene encoding a target for isoniazid and ethionamide in Mycobacterium tuberculosis. Science 263: 227-230, 1994.

[142]. Schaeffer ML, Agnihotri G, Volker C, Kallender $\mathrm{H}$, Brennan PJ, Lonsdale JT. Purification and biochemical characterization of the mycobacterium tuberculosis $\beta$-ketoacyl-acyl carrier protein synthases KasA and KasB. J Biol Chem 276: 47029-47037, 2001.

[143]. Kremer L, Douglas JD, Baulard AR.and 9 other authors. Thiolactomycin and related analogues as novel anti-mycobacterial agents targeting KasA and KasB condensing enzymes in Mycobacterium tuberculosis. J Biol Chem 275: 16857-16864, 2000.

[144]. Morita YS, Paul KS, Englund PT. Specialized fatty acid synthesis in African trypanosomes: myristate for GPI anchors. Science 288: 140$143,2000$.

[145]. Douglas JD, Senior SJ, Morehouse C, Phetsukiri B, Campbell IB, Besra GS, Minnikin DE. Analogues of thiolactomycin: Potential drugs with enhanced anti-mycobacterial activity. Microbiology 148: 3101-3109, 2002.
[146]. Senior SJ, Illarionov PA, Gurcha SS, Campbell IB, Schaeffer ML, Minnikin DE, Besra GS. Biphenyl-based analogues of thiolactomycin, active against mycobacterium tuberculosis $\mathrm{mtFabH}$ fatty acid condensing enzyme. Bioorg Med Chem Lett, 13: 3685-3688, 2003.

[147]. Senior SJ, Illarionov, PA, Gurcha SS, Campbell IB, Schaeffer ML, Minnikina DE Besra GS. Acetylene-based analogues of thiolactomycin, active against mycobacterium tuberculosis $\mathrm{mtFabH}$ fatty acid condensing enzyme. Bioorg Med Chem Lett 14: 373-376, 2004.

[148]. Bhowruth V, Brown AK, Senior SJ, .Snaith JS, Besra GS. Synthesis and biological evalution of a C5-biphenyl thiolactomycin library. Bioorg Med Chem Lett 17: 5643-5646, 2007.

[149]. Kim P, Zhang Y, Shenoy G, Nguyen Q, Boschoff HI, Manjunath UH, Goodwin MB, Lonsdale J, Price AC, Miller DJ, Duncan K, White SW, Rock CO, Barry III CE, Dowd CS. Structure-Activity Relationships at the 5-Position of thiolactomycin: An intact (5R)-isoprene unit is required for activity against the condensing enzymes from mycobacterium tuberculosis and Escherichia coli. J Med Chem 49: 159-171, 2006.

[150]. McFadden JM, Medghalchi SM, Thupari JN, Pinn ML, Valamudi A, Miller KI, Kuhajda FP, Townsend CA. Application of a flexible synthesis of (5R)-thiolactomycin to develop new inhibitors of type I fatty acid synthase. J Med Chem 48: 946-971, 2005.

[151]. Kamal A, Shaik AA, Sinha R, Yadav JS, Arora SK. Antitubercular agents. Part 2: New thiolactomycin analogues active against mycobacterium tuberculosis. Bioorg Med Chem Lett 15: 1927-1929, 2005.

[152]. Jones SM, Urch JE, Brun R, Harwood JL, Berry $\mathrm{C}$, Gilbert IH. Analogues of thiolactomycin as potential anti-malarial and anti-trypanosomal agents. Bioorg. Med. Chem., 12: 683-692, 2004.

[153]. Jones SM, Urch JE, Kaiser M, Brun R., Harwood JL, Berry C, Gilbert IH. Analogues of thiolactomycin as potential antimalarial agents. J Med Chem 48: 5932-5941, 2005.

[154]. Sakaya SM, Contreras MS, Dirlam JP, O'Connell TN, Hayashi SF, Santoro SL, Kamicker BJ, George DM, Ziegler CB. Synthesis and structure-activity relationships of thiotetronic acid analogues of thiolactomycin. Bioorg Med Chem Lett 11: 2751-2754, 2001. 